\title{
Obituary.
}

Prof. J. G. Adami, C.B.E., F.R.S.

GEORGE ADAMI was a great pathologist, though $G$ not a ' laboratory man 'in later years. A scholar and Darwin prizeman of Christ's College, Cambridge, he took a first class in the Natural Science Tripos, then studied in Paris with Pasteur and Roux, in Breslau with Heidenhain, and in Cambridge with Roy and Michael Foster. Afterwards he became John Lucas Walker student, and at the early age of thirty, professor of pathology and bacteriology at McGill University, Montreal. Through his inspiration, Sir Humphry Rolleston has written: " a continuous stream of papers" issued "from his laboratory dealing with all branches of pathology and its application to other sciences." He was awarded the F.R.S. in 1905 and the Fothergillian gold medal of the Medical Society of London in 19I4. He was an ex-president of the Association of American Physicians, a fellow of both Jesus and Christ's Colleges, and held many honorary degrees. During the War, Adami became assistant director of Medical Services in the Canadian Army, for which he received the C.B.E. A member of the War Office Committee on the Medical History of the War, he published in I9I8 vol. I of the "War Story of the Canadian Medical.Corps." He was chairman of the Committee on Bacteriological Procedures, Medical Research Committee, and was largely responsible for the standardisation of Wassermann technique in the laboratories of Great Britain.

Adami's greatest contribution to science was the "Principles of Pathology." The first volume on general pathology, published in I908, marked an epoch. It was, as stated in the preface, " not a mere record and description of phenomena, but an attempt to analyse those phenomena in an ordinary manner." It contained his exposition of inflammation and his original and helpful classification of neoplasms upon an embryological basis. Four years later he published with his friend Dr. John McCrae, of McGill University, his popular text-book of pathology. Other contributions to science included "The Physiology and Pathology of the Mammalian Heart" with Roy (Phil. Trans.), Pictou cattle disease, and a survey of the I918 influenza epidemic in the British Army. In his Croonian lectures on adaptation and disease, delivered at the Royal College of Physicians in 1917 , Adami argued against the doctrine that acquired characters are not transmitted. He was greatly interested in the problem of malignancy, and in the Medical Journal and Record, New York, August I8, I926, controverted the view "that one particular order of microbe is concerned in the production of all malignant tumours ;" he believed that the colloidal lead treatment was an "advance."

Adami accepted in rgrg the arduous post of vicechancellor of the University of Liverpool. By his broad and practical outlook on life, his buoyant energy, his genial friendship, and his high ideals, he ennobled the University and the City of Liverpool and brought the two into closer and more intimate relationship. He faced his gradually failing health with unflinching courage, carrying out his duties to within a few weeks of his death.

ERNEST GlynN.
The news of Vice-Chancellor Adami's death came as a great shock to his personal friends, and no man had more: for so great was his passion for pleasant intercourse, and his enjoyment of human fellowship, that he sought and made firm friendships where other men would have only multiplied acquaintances. To meet him was a pleasure which he always actively developed, striking sparks from stones, and even finding entertainment in dullards. Doubtless it was partly this side of his character which found satisfaction in the very onerous post of vice-chancellor in the midst of this busily employed provincial city : a post which he filled with distinction, and with a grace which few could imitate. Not very different was that other interest which could leave no medical problem untouched, and carried him, enthusiastically always, through the wide-spread fields of knowledge in the subject of which he was a master, ever curious to meet new developments and always with the firm hand which grasped what others were satisfied with merely touching.

Gifted with this spirit of adventurous and penetrating curiosity, a man of incessant industry, and with a natural facility of expression and delight in exposition, his scientific papers and lectures have since his earliest days excited marked admiration: and to many it was a matter for regret that this more widely-known side of his activities was submerged in the daily routine of an administrative post. However, in Liverpool, an occasional lecture to a local society frequently disclosed the talents which his administrative duties otherwise concealed: and even to those to whom his main subject was a closed book, he was a shining example of the light which the University represented in the lives of the younger generation to which he patiently struggled to make it more and more accessible.

Resident long in Canada, familiar with methods of co-operation better known there than in our more conservative home-surroundings, Adami was sincerely an advocate of modes of procedure, methods and manners of organisation, which are not quite our own : and this advocacy was not without some discovery that habits and tastes were not readily remodelled. Such surprises must come to every man of action who ventures into new fields, and there the weaker spirit fails. Adami's spirit never flinched. Through every temporary conflict his buoyancy survived, and the geniality of his character helped him ably to overcome any lingering remnant of hostility.

Nor is this perhaps without some application to the endeavours in medical progress with which Adami has been most closely associated in the last few years of his life. Cancer, as he phrased it, is a killer, therefore it must be fought, and that by team-roork. Absolute sincerity, tremendous enthusiasm, great breadth of knowledge and keenness of insight, and yet opposition, as natural as the clouds, which he somehow failed to understand.

Splendid gifts, sturdily continued efforts, great endeavours, all carried in a nature that was poised and balanced as by an internal gyrostat of goodwill and honourable intention; none of these qualities have

NO. 2969, VOL. II8] 
been without success in the realms of science, medicine, and affairs. In Liverpool his efforts to strip the University of its shell and bare it to the life of the City have left a permanent effect of greatest value, by which he will be remembered here for many years to come. Vale!

J. S. Macdonald.

DR. J. L. F. Dreyer.

ON September r4, Dr. John Louis Emil Dreyer died at the age of seventy-four years from an illness which he had resisted for the greater part of a year with an astonishing vitality. By his death astronomers are deprived of the presence of one of the most distinguished historians of their science. There are others who have treated the history of astronomy more comprehensively, but within the wide range of his labours there is certainly none who has excelled Dr. Dreyer in the combination of learning, sagacity, scholarly precision, and clear and well proportioned exposition.

Dr. Dreyer was descended from a family which had long been distinguished, largely as soldiers, in the public service of Denmark. The son of LieutenantGeneral F. Dreyer, he was born at Copenhagen in $185^{2}$ and was educated at the University of Copenhagen. In 1874 he came to Ireland as astronomer at Lord Rosse's Observatory at Birr Castle. Lord Rosse's famous telescope had been found to be specially adapted to the observation of nebulæ, and Dreyer in consequence embarked on the study of nebulæ, with which, next to his studies in the history of astronomy, his name is most closely associated. In 1878 his work on nebulæe was interrupted by his appointment as assistant astronomer at the Royal Observatory at Dunsink, but it was revived on his appointment in $\mathrm{I} 882$ to be director of the Armagh Observatory. While at Birr he prepared for publication the whole series of observations made with Lord Rosse's telescope from I 848 to 1878 , published by Lord Rosse in the Transactions of the Royal Dublin Society, I880, and he also published a supplement to Herschel's catalogue of nebulæ with numerous corrections. At Armagh, in addition to minor studies on nebulæ, he produced in I 888 the "New General Catalogue of Nebulæ and Clusters of Stars," included in the forty-ninth volume of the Memoirs of the Royal Astronomical Society, which, with his two supplementary catalogues published in the same series in I895 (vol: $5 \mathrm{I}$ ) and 1908 (vol. 59), form the standard catalogues to which reference is always made.

While at Dunsink, Dreyer joined Copeland in founding an international astronomical journal called Urania, the first number of which appeared in January I88x. In July of that year its name was changed to Copernicus. The last number appeared in June 1884. The editors contributed their full share of reports and articles, and the journal is full of matter which, after more than forty years, remains both interesting and instructive. Dreyer's most important contribution was his "New Determination of the Constant of Precession," vol. 2, pp. I35-I55, which, though never adopted in practical work, was used by Newcomb in his classical determinations.

At Armagh Dreyer produced in I 886 the "Second Armagh Catalogue of 3300 Stars," but his subsequent publications have been restricted to nebulæ and astronomical history. In 1890 he produced "Tycho
Brahe, a Picture of Scientific Life and Work in the Sixteenth Century." Danish patriotism has given rise to much research on Tycho Brahe, but Dreyer found no scholarly biography, which should at once establish the facts in the light of the evidence available and at the same time place Tycho in his true position in relation to the progress of astronomy and to the life and thought of his time. Dreyer's volume, which is as illuminating as it is scholarly, supplies this want. In I $\mathrm{I}_{3}$ he began the publication of a complete edition of Tycho's works, of which ten volumes have appeared and the remaining four are stated to be complete in manuscript. This edition must probably be regarded as in the main a work of piety. The preparation of the text must have been a laborious task. The notes, in Latin, are brief, but exhibit the editor's usual scholarship. He has among other things taken the pains to discover what editions of the classics Tycho used.

In Igo6 appeared Dreyer's "History of Planetary Systems from Thales to Kepler." The history of planetary systems for those ages is practically. the history of astronomical theory. Here as usual we find that mastery of authorities and that sober judgment in weighing doubtful evidence that we should expect from a scholar alone, combined with that skilful interpretation and sympathetic exposition that only an astronomer could give. Dreyer returned to parts of this subject in two papers contributed to Monthly Notices of the Royal Astronomical Society in 1917 and 1918 , in which he effectively disposed of the long prevailing idea that Ptolemy's star catalogue did not rest on his own observations, but on those of Hipparchus or Menelaus reduced to his own time. In 1920 he succeeded, largely as a result of research on manuscripts at Oxford, in restoring the original form of the Alfontine Tables (Mon. Not. R.A.S., vol. 8o, pp. 243-62). He took the leading part in the editing of Sir William Herschel's "Scientific Papers," published in 1912, and a very large share in the volume which the Royal Astronomical Society has recently produced on the first hundred years of its history.

Distinctions came as a matter of course. In I916 Dreyer received the gold medal of the Royal Astronomical Society, of which he was president from $I 923$ until 1925 . He received the honorary degree of D.Sc. from the University of Belfast, and of M.A. from the University of Oxford, in which city he had settled on his retirement from Armagh in 1916.

In private life Dreyer was unobtrusive, but accessible. He spoke quietly, and with the same deliberation and authority with which he expressed himself in public. His learning was always available to those who wished to benefit by it, and he will be greatly missed. His wife, a daughter of John Tuthill, of Kilmore, Co. Limerick, whom her friends hold in affectionate remembrance, died in r923. He leaves three sons, all distinguished in the fighting services of the British Crown, and one daughter, who is married to $\mathrm{Mr}$. Warham Shaw-Hamilton, late of Dartan, Co. Armagh.

\section{Mr. J. H. Mummery, C.B.E.}

ThE death of John Howard Mummery on August 30 , whilst on a holiday visit to Cornwall, deprives the world of an eminent microscopist. Born on January 19,

NO. 2969, VOL. II8] 